\title{
Variabel Forgiveness Ditinjau Dari Religiusitas Pada Remaja
}

\author{
Tugimin Supriyadi ${ }^{1}$, Zahra Afifah Rahman ${ }^{1}$, Tiara Anggita Perdini ${ }^{1, *}$ \\ ${ }^{1}$ Fakultas Psikologi; Universitas Bhayangkara Jakarta Raya; Jl. Perjuangan 081, Marga Mulya, \\ Bekasi Utara; 02188955882/ +622188955871; e-mail: tugimin.supriyadi@gmail.com, \\ zahrafazalia18@gmail.com, tiaraanggitaperdini@gmail.com \\ * Korespondensi: e-mail: tiaraanggitaperdini@gmail.com
}

Submitted: 29/09/2020; Revised: 14/12/2020; Accepted: 30/12/2020; Published: 15/01/2021

\begin{abstract}
Every day individuals must carry out social activities such as communicating with each other. The communication process makes individuals more mature in dealing with problems, as well as adolescents. Communication carried out sometimes does not run smoothly and causes disappointment between individuals. This disappointment can disappear with a sense of sincerity and forgiveness that is done. One of the forgiveness factors is religiosity. Individuals can do forgiveness based on their belief in religion as a basis for behavior. Through this research, the researcher wanted to analyze the forgiveness through survey study research. The research data were obtained from the distribution of the forgiveness variable scale and the religiosity variable scale. Taking research subjects here using a stratified random sampling technique, in which the subject is taken randomly based on class level. This study involved as many as 150 adolescents, 118 women and 32 men. The results of this study showed that the variable of religiosity was proven to affect the forgiveness variable. In addition, empirical facts were also found, namely the difference in the level of forgiveness in the class groups. As for the level of religiosity in the class group, there was no difference. Likewise with the level of forgiveness in the gender group and the level of religiosity in the gender group. For future research, it is necessary to analyze the forgiveness variable in subjects with adult age vulnerability. This is necessary to see the process of forgiveness development in terms of age.
\end{abstract}

Keywords: Adolscent, Forgiveness, Religious

\begin{abstract}
Abstrak
Setiap harinya individu pasti melakukan aktivitas sosial seperti berkomunikasi satu sama lain. Proses komunikasi menjadikan individu lebih dewasa dalam menyikapi permasalahan, begitu juga dengan remaja. komunikasi yang dilakukan terkadang tidak berjalan lancer dan menyebabkan kekecewaan antar individu. Kekec ewaan tersebut dapat menghilang dengan adanya rasa ikhlas dan forgiveness yang dilakukan. Salah satu faktor forgiveness adalah religiusitas. Individu dapat melakukan forgiveness berdasarkan dengan keyakinannya terhadap agama sebagai dasar bertingkah laku. Melalui penelitian ini, peneliti ingin menganalisis terkait mengenai forgiveness melalui penelitian studi survey. Data penelitian didapatkan dari penyebaran skala variabel forgiveness dan skala variabel religiusitas. Pengambilan subjek penelitian disini menggunakan teknik stratified random sampling, yang dimana subjek diambil secara random berdasarkan tingkatan kelasnya. Penelitian ini melibatkan sebanyak 150 remaja, 118 perempuan dan 32 laki-laki. Hasil penelitian ini mendapatkan hasil yaitu bahwa variabel religiusitas terbukti dapat mempengaruhi variabel forgiveness. Selain itu, ditemukan juga fakta empiris yaitu adanya perbedaan tingkat forgiveness pada kelompok kelas. Sedangkan untuk tingkat religiusitas pada kelompok kelas, tidak ditemukan perbedaan. Begitu juga dengan tingkat forgiveness pada kelompok jenis kelamin dan tingkat religiusitas pada kelompok jenis kelamin. Untuk penelitian kedepannya perlu untuk menganalisis variabel forgiveness pada
\end{abstract}


subjek dengan rentan usia dewasa. Hal ini diperlukan untuk melihat proses perkembangan forgiveness dari segi usia.

Kata kunci: Remaja, Forgiveness, Religiusitas

\section{Pendahuluan}

Masa remaja adalah salah satu masa perkembangan akan dilewati oleh setiap manusia. Masa remaja dimulai dari usia 10-12 tahun dan berakhir pada usia 18-22 tahun (Santrock, 2012). Dalam perkembangan tumbuh kembang remaja cenderung erat dengan perubahan fisik, psikologis, pola pikir dan tantangan dalam hidup (Nur Utami \& Raharjo, 2019). Banyak perubahan yang dialami remaja, baik secara fisik maupun secara mental membuat mereka harus bisa beradaptasi dan tetap berinteraksi sosial dengan individu-individu lain di sekitarnya (Colegrove, Havighurst, Kehoe, \& Jacobsen, 2018). Dilihat lebih mendalam lagi, karakteristik pada diri remaja terbentuk oleh beberapa faktor yang secara intens melakukan interaksi sosial dan berkomunikasi seperti keluarga (Hutahaean et al., 2020), lingkungan sosial (Mustika \& Sahudra, 2018), dan agama (Junaedi, 2019). Dalam proses berinteraksi atau berkomunikasi juga tak jarang menciptakan sebuah konflik permasalahan dan memicu pertengkaran. Mulai dari permasalahan kecil sampai permasalahan yang besar. Permasalahan atau konflik merupakan hal yang dramatik, yang mengarah kepada pertarungan atau pertikaian antara dua kubu dan adanya suata action dan balasan (Wellek \& Werren, 2014). Permasalahan tersebut biasanya dipicu oleh beragam motif (Tisatin, 2019) seperti adanya rasa marah, sakit hati, perasaan dendam, kecewa, bahkan terluka. Jika dalam tahapan interaksi komunikasi sudah terjadi adanya konflik permasalahan, maka kualitas suatu hubungan akan menjadi berubah dan bahkan akan sulit untuk menjalin hubungan yang harmonis kembali. Dapat dilihat bahwa setiap saat dan seterusnya, hubungan interpersonal seseorang dapat terganggu dan terluka (Simorangkir, 2019). Dalam usaha mengurangi atau bahkan menghilangkan rasa marah, dendam dari konflik permasalahan yang terjadi salah satunya adalah dengan melalui perilaku saling memaafkan (Alentina, 2016).

Pemaafan atau bisa juga disebut dengan forgiveness menjadi salah satu solusi atau jalan keluar dari berbagai ragam cara dalam menyelesaikan perkara dan sebuah usaha agar suatu hubungan dapat terjalin kembali seperti semula. Forgiveness merupakan salah satu tatanan dari nilai-nilai moral yang harus dimiliki pada setiap manusia (Lin, Enright, \& Klatt, 2011). Oleh karena itu, penting perilaku forgiveness diajarkan sejak anak-anak, agar individu mampu menjadi pribadi yang positif dalam berinteraksi dan berkomunikasi (Manik, 2017). Menurut Goss (2002) Perilaku Forgiveness memiliki empat bentuk perilaku diantaranya yaitu; yang pertama adalah hollow forgiveness yaitu individu mengucapkan pemaafan tapi secara internal masih menyimpan dendam, kedua silent forgiveness yaitu individu tidak mengucapkan pemaafan namun secara internal telah memaafkan dan mengikhlaskan (berkebalikan dengan hollow forgiveness), yang ketiga yaitu total forgiveness yang dimana dalam hal ini individu mengungkapkan dan benar-benar merasakan juga pemaafannya tersebut, yang terakhir adalah 
unforgiveness dimana individu tidak mengeksperikan dan juga tidak mengungkapkan pemaafan. forgiveness seringkali di uraikan sebagai salah satu tahapan proses untuk menggantikan emosi negatif dari setiap individu seperti rasa marah dan menjauhi pelaku tersebut yang kemudian menjadikan emosi yang lebih positif bahkan terkadang menciptakan adanya rasa belas kasihan terhadap pelaku (Worthington, 2005).

Perilaku forgiveness juga timbul melalui proses-proses tertentu. Menurut McCullough, Rachal, \& Worthington (1997) ada empat fase seseorang dapat mengampuni orang lain, diantaranya yaitu; yang pertama merupakan fase pengungkapan dimana individu mengalami rasa sakit atau kekecewaan yang diakibatkan oleh individu lain, fase yang kedua merupakan fase pengambilan keputusan dimana dalam fase ini individu mengambil keputusan untuk mengampuni atau tidak, fase ketiga adalah fase bertindak (action) dimana individu telah melakukan tindakan terhadap individu lain yang telah menyakitinya, kemudian fase terakhir yaitu kebermaknaan dimana individu sadar bahwa memaafkan dapat memberikan manfaat bagi dirinya dan orang lain. Sebagai remaja pastinya diharapkan untuk bisa memaafkan kesalahankesalahan individu lain, baik kesalahan yang kecil maupun kesalahan besar, serta dengan adanya kesediaan seseorang untuk meninggalkan kemarahan, penilaian negatif, dan perilaku acuh-tidak acuh terhadap orang lain yang telah menyakitinya secara tidak adil (Lin et al., 2011).

Perilaku forgiveness tidak secara tiba-tiba muncul begitu saja. Terdapat berbagai macam faktor-faktor lain yang mempengaruhi individu untuk dapat mengeluarkan perilaku forgiveness terhadap individu lain. Faktor forgiveness antara lain yaitu empati, keramahan atau kedekatan, perasaan malu kedekatan hubungan dengan pelaku, kualitas hubungan interpersonal sebelum kejadian, luka yang ditimbulkan oleh pelaku, permintaan maaf, dan religiusitas (agama) (Wade \& Worthington, 2003). Salah satu faktor yang ditarik untuk dijadikan fokus perhatian dalam penelitian ini adalah religiusitas yang membuat individu mampu untuk memaafkan individu lain. Dalam penelitian McCullough, Rachal, \& Worthington (1997) ditemukan bahwa individu yang memiliki tingkat religious tinggi, akan dengan mudah menerapkan perilaku forgiveness dibandingkan dengan tingkat religious individu yang rendah. Religious didapatkan identik dengan religiusitas, ortodoksi, keyakinan agama, kesholehan, pengabdian dan dalam agama Kristen kekudusan (Simorangkir, 2019). Religiusitas merupakan komponen komponen intern agama dalam diri individu, maksudnya yaitu keyakinan individu kepada ajaran-ajaran agama (Aviyah \& Farid, 2014). Religiusitas sendiri adalah pengaruh yang dapat memotivasi individu dalam melakukan aktivitas, suatu perbuatan karena didasari oleh adanya keyakinan agama dianggap mempunyai unsur kesucian dan ketaatan (Amrila \& Widodo, 2015). Religiusitas menjadi komponen penting yang memiliki pengaruh positif (happiness) terhadap remaja (Ru, Diponegoro, Cahyo, \& Kistoro, 2020). Religiusitas perlu diperkenalkan kepada remaja, pengenalan religiusitas tersebut dapat melalui indra penglihatan, indra pendengaran, dan juga pengalaman masa kecil (Nuwairah, 2015). Individu yang telah menanamkan nilai religiusitas sedari kecil, hal ini akan sangat bermanfaat dalam pengembangan sikap moralnya (Rizqina \& Suratman, 2020). Pada hakikatnya, 
Mengembangkan sifat religiusitas hendaknya menjadi bahan pertimbangan untuk kesadaran akan suatu keyakinan dan pemahaman agama yang dimiliki oleh setiap individu atas kejadian yang telah terjadi.

Penelitian sebelumnya yang dilakukan oleh Fox \& Thomas (2008), penelitian ini menemukan bahwa variabel religiusitas (keyakinan terhadap tuhan) menjadi predictor terkuat dalam individu melakukan perilaku forgiveness. Dalam penelitian sebelumnya juga pernah membahas mengenai hubungan religious dan forgiveness, hasilnya variabel forgiveness dan variabel religiusitas memiliki hubungan yang positif dan searah (Amrila \& Widodo, 2015). Khasan (2017) juga memberikan penelitian di tahun sebelumnya, hasil dari penelitian ini yaitu bahwa forgiveness dipengaruhi oleh religiusitas dan forgiveness merupakan sebuah kepribadian yang secara kuat mengeluarkan ekspresi kecenderungan untuk menghindari balas dendam, menciptakan perdamaian, menjaga hubungan baik, dan mementingkan keselamatan semua makhluk. Melalui penelitian ini, peneliti ingin meninjau kembali variabel forgiveness ditinjau dari variabel religiusitas guna untuk melihat kebaharuan apa yang bisa didapat, terutama dalam analisis uji beda masing-masing variabel pada kelompok penelitian.

\section{Metode Penelitian}

Penelitian ini dilakukan dengan melalui pendekatan studi survey terhadap variabel forgiveness (variabel terikat) dan variabel religiusitas (variabel bebas). Subjek dalam penelitian berjumlah sebanyak 150 individu yang diambil dari siswa-siswi SMA "X" yang beragama Islam dan berada pada rentangan usia remaja (15 - 18 tahun). Subjek-subjek tersebut dipilih dengan menggunakan teknik probability sampling, stratified random sampling. Stratified random sampling merupakan teknik pengambilan data penelitian melalui tahapan pembagian populasi ke dalam strata atau tingkatan (Acharya, Prakash, Saxena, \& Nigam, 2013). Sampel penelitian diambil secara random atau acak berdasarkan setiap tingkatannya. Data penelitian studi survey didaperoleh dari penyebaran kusioner skala. Adapun skala yang disebar yaitu skala Forgiveness dan skala Religiusitas. Kusioner skala tersebut disebarkan melalui google form, karena penelitian ini dilaksanakan ketika sedang terjadi pandemi covid-19. Kemudian, setelah data subjek didapatkan, maka akan dilakukan analisis data melalui pendekatan kuantitatif. Pendekatan kuantitatif adaah pendekatan analisis dengan menggali keterangan hasil melalui data berupa angka-angka.

Penelitian ini akan melakukan beberapa tahapan analisis. Analisis pertama yang dilakukan yaitu uji diskriminasi butir item. Hal ini diperlukan untuk melihat apakah alat ukur yang digunakan dalam penelitian ini dapat diandalkan atau tidak (Azwar, 2017). Keterandalan tersebut ditentukan berdasarkan standar nilai reliabilitas dan juga standar nilai validitas pada masing-masing item (Karsidi, 2000). secara lebih detail, variabel forgiveness terdiri dari 48 butir item sedangkan variabel religiusitas terdiri dari 24 butir item awal. Nantinya, item yang tidak memenuhi standar akan digugurkan dan item yang memenuhi standar akan digunakan kembali pada pengambilan data karena dinilai layak untuk mengukur variabel. Analisis kedua yaitu studi 
survey, yang didalamnya memuat tentang uji normalitas, uji regresi dan uji beda antara variabel dengan kelompok-kelompok subjek. Uji normalitas penting digunakan untuk melihat apakah data terdistribusi secara normal atau tidak. data yang terdistribusi normal dapat dilihat dengan besaran nilai yang berpusat kepada nilai median (Jaya, Maryana Kuswandi \& Mulyadi, 2012). Selain itu, tujuan diadakannya analisis uji normalitas yaitu agar dapat ditentukan teknik analisis kedepannya. Uji regresi juga diperlukan untuk mengetahui bagaimana interaksi secara langsung maupun tidak langsung antara kedua variabel dan seberapa besar interaksi yang terjadi diantara kedua variabel. Selain itu, uji regresi juga digunakan untuk melihat nilai variabel terikat berdasarkan nilai variabel bebas serta untuk mengetahui koefisien determinan (Sugiyono, 2014). Dalam penelitian ini, uji regresi yang digunakan adalah analisis uji regresi linier sederhana. Kemudian uji beda akan dilakukan juga guna untuk melihat perbedaan variabel Forgiveness dan variabel religiusitas pada kelompok-kelompok subjek. Adapun kelompok-kelompok subjek yang turut dianalisa yaitu tingkat kelas sekolah dan jenis kelamin (gender) subjek.

\section{Hasil dan Pembahasan.}

\subsection{Uji Coba Alat Ukur}

Pada penelitian ini, alat ukur yang digunakan yaitu skala kuesioner forgiveness dan skala kuesioner religiusitas. Uji coba alat ukur pada penelitian ini menggunakan uji diskriminasi daya beda item guna untuk melihat nilai koefisien korelasi (validitas) dan koefisien alpha (reliabilitas) pada masing-masing butir item (Azwar, 2017). Kemudian item-item yang tidak memenuhi nilai standarisasi koefisien korelasi akan digugurkan sedangkan item lainnya akan dipertahankan untuk kemudian digunakan dalam pengambilan data penelitian. Adapun standarisasi nilai yang digunakan pada penelitian ini, Koefisien alpha menggunakan standarisasi nilai 0,3 yang berarti item dengan nilai koefisien alpha diatas atau sama dengan 0,3 dianggap valid (Priyatno, 2012). Sedangkan untuk nilai koefisien alpha, standarisasi nilai yang digunakan adalah 0,7 yang berarti item dengan nilai koefisien alpha diatas atau sama dengan 0,7 dianggap reliabel (Priyatno, 2012).

Tabel 1. Uji Diskriminasi Item Alat Ukur

\begin{tabular}{|c|c|c|c|c|c|}
\hline Skala Yang Diuji & Koefisien Korelasi & $\begin{array}{c}\text { Koefisien } \\
\text { Alpha }\end{array}$ & $\begin{array}{c}\text { Item Uji } \\
\text { Coba }\end{array}$ & Item Gugur & $\begin{array}{c}\text { Item } \\
\text { Layak }\end{array}$ \\
\hline Forgiveness & $0,301-0,681$ & 0,906 & 48 & 12 & 36 \\
\hline Religiusitas & $0,306-0,697$ & 0,886 & 24 & 2 & 22 \\
\hline
\end{tabular}

Sumber: Hasil Pengolahan Data (2020)

Hasil pada uji diskriminasi diatas menjelaskan bahwa variabel forgiveness memiliki item gugur sebanyak 12 item dari 48 item dan menyisahkan item yang layak sebanyak 36 item. Dari 36 item, dapat diketahui nilai koefisien korelasi berkisar antara 0,301-0,681 $>0,3$, ini artinya ke 36 item tersebut valid. Kemudian nilai koefisien alpha pada variabel forgiveness diketahui sebesar 0,906 > 0,7 yang artinya item item tersebut reliabel. Sedangkan pada variabel 
religiusitas, item yang gugur sebanyak 2 item dari 24 item diawal dan menyisahkan 22 item yang layak. Hasil koefisien korelasi dari variabel religiusitas berkisar antara 0,306-0,697 >0,3, ini berarti item-tem tersebut valid. Lalu dapat diketahui juga nilai koefisien alpha pada variabel religiusitas yaitu sebesar 0,886 $>0,7$ yang artinya item-item tersebut reliabel. Dengan ini, item yang akan dipakai pada pengambilan data penelitian sebanyak 36 item dari variabel forgiveness dan 22 item dari variabel religiusitas, sedangkan item-item lainnya akan digugurkan karena tidak sesuai dengan standarisasi nilai yang telah ditetapkan.

\subsection{Uji Normalitas}

Uji normalitas ini diperlukan untuk mengetahui apakah data terdistribusi secara normal atau tidak, sehingga peneliti dapat menentukan teknik analisa berikutnya, apakah menggunakan analisa parametric atau analisa non-parametrik (Periantalo, 2016). Nilai standarisasi yang digunakan dalam uji normalitas adalah diatas atau sama dengan 0,05 (Widhiarso, 2012). Adapun hasil uji normalitas yang dapat dilihat pada tabel 2.

Tabel 2. Uji Normalitas

\begin{tabular}{ccc}
\hline Variabel & Jumlah Subjek & Nilai Normalitas \\
\hline Forgiveness & 150 & 0,200 \\
\hline Religiusitas & 150 & 0,000
\end{tabular}

Sumber: Hasil Pengolahan Data (2020)

Tabel 2 menunjukan hasil terhadap 150 subjek hasil yang ada yaitu, pada variabel forgiveness dapat dilihat nilai normalitas sebesar $0,200>0,05$, yang artinya variabel forgiveness terdistribusi normal. Kemudian pada variabel religiusitas ditemukan nilai normalitas sebesar $0,000<0,05$, ini menandakan bahwa variabel religiusitas tidak terdistribusi normal. Dari hasil kedua variabel tersebut, terlihat jika salah satu variabel tidak terdistribusi normal (variabel religiusitas), maka teknik analisa yang selanjutnya akan dipakai yaitu menggunakan analisa non-parametric (Santoso, 2010).

\subsection{Analisis Deskriptif}

Analisis deskriptif juga digunakan pada penelitian ini guna untuk melihat kelompokkelompok subjek yang termasuk dalam penelitian ini. Subjek dalam penelitian ini adalah remaja yang berasal dari siswa-siswi SMA " $x$ " dengan total keseluruhan subjek berjumlah 150 orang.

Tabel 3. Uji Deskriptif

\begin{tabular}{cccc}
\hline Kelompok & Kategori & Jumlah & Presentase (\%) \\
\hline \multirow{2}{*}{ Jenis Kelamin } & Laki-Laki & 32 & 21,3 \\
\cline { 2 - 4 } & Perempuan & 118 & 78,7 \\
\hline \multirow{2}{*}{ Kelas } & X (sepuluh) & 22 & 14,7 \\
\cline { 2 - 4 } & XI (sebelas) & 62 & 41,3 \\
\cline { 2 - 4 } & XII (dua belas) & 66 & 44,0 \\
\hline Total & & 150 & 100
\end{tabular}

Sumber: Hasil Pengolahan Data (2020)

Data pada tabel diatas memperlihatkan total keseluruhan subjek berjumlah 150 orang dengan perincian yaitu subjek berjenis kelamin laki-laki berjumlah 32 orang $(21,3 \%)$, dan subjek 
berjenis kelamin perempuan berjumlah 118 orang $(78,7 \%)$. Dalam kelompok jenis kelamin, kategori subjek perempuan berada di posisi paling atas dengan subjek terbanyak. Selanjutnya pada kelompok kelas, subjek dari kelas $\mathrm{X}$ berjumlah 22 orang $(14,7 \%)$, subjek dari kelas XI berjumlah 62 orang $(41,3 \%)$, kemudian subjek dari kelas XII berjumlah 66 orang $(44,0 \%)$. Dapat dilihat pada kelompok kelas jika kelas XII berada di posisi tertinggi dengan subjek terbanyak dan kelas $\mathrm{X}$ berada di posisi terendah dengan subjek paling sedikit.

\subsection{Analisis Kategorisasi}

Analisis kategorisasi dipakai dalam penelitian ini, prosesnya dilakukan menggunakan rumus mean hipotetik berdasarkan jumlah skor pada masing-masing subjek. Analisis kategorisasi akan dibagi menjadi 5 kelompok yaitu rendah, agak rendah, sedang, agak tinggi, dan tinggi. Hasil kategorisasi dapat dilihat pada tabel dibawah ini

Tabel 4. Uji Kategorisasi

\begin{tabular}{|c|c|c|c|c|}
\hline Variabel & Kategorisasi & $\begin{array}{c}\text { Jumlah Skor } \\
\text { Subjek }\end{array}$ & Jumlah & Presentase (\%) \\
\hline \multirow{5}{*}{ Forgiveness } & Rendah & $<60$ & 0 & 0 \\
\hline & Agak Rendah & $60-84$ & 0 & 0 \\
\hline & Sedang & $84-132$ & 59 & 39,3 \\
\hline & Agak Tinggi & $132-156$ & 66 & 44 \\
\hline & Tinggi & $>156$ & 25 & 16,7 \\
\hline \multirow{5}{*}{ Religiusitas } & Rendah & $<36,8$ & 0 & 0 \\
\hline & Agak Rendah & $36,8-51,4$ & 0 & 0 \\
\hline & Sedang & $51,4-80,6$ & 2 & 1,3 \\
\hline & Agak Tinggi & $80,6-95,2$ & 21 & 14 \\
\hline & Tinggi & $>95,2$ & 127 & 84,7 \\
\hline
\end{tabular}

Sumber: Hasil Penelitian (2020)

Tabel 4 menjelaskan mengenai hasil dari uji kategorisasi. Dalam penelitian ini terdapat dua variabel yang dilakukan uji kategorisasi. Variabel pertama adalah variabel Forgiveness, dimana terdapat lima kelompok kategorisasi yaitu rendah, agak rendah, sedang, agak tinggi, dan tinggi. kategorisasi rendah adalah kelompok dengan jumlah skor nilai dibawah 60 dan pada kelompok ini tidak terdapat satu pun subjek $(0 \%)$, begitu juga dengan kelompok kategorisasi agak rendah dengan jumlah skor berkisar antara 60-84 dimana tidak terdapat satu pun subjek $(0 \%)$. Kelompok berikutnya yaitu kelompok kategorisasi sedang dengan jumlah skor berkisar antara $84-132$, kelompok ini memiliki total subjek sebanyak 59 orang $(39,3 \%)$. Yang keempat adalah kelompok dengan kategorisasi agak tinggi, kelompok ini memiliki jumlah skor subjek yang berkisar antara 132-156, dan dari 150 subjek terdapat 66 (44\%) subjek yang berada pada kategori ini. Kemudian ada pun kelompok kategorisasi tinggi dengan skor total lebih dari 156, pada kelompok ini terdapat 25 (16,7\%) orang. Individu dengan perilaku forgiveness rendah, akan semakin memiliki dorongan untuk membalas dendam atau menghindar tanpa adanya pengampunan, sedangkan individu dengan perilaku forgiveness tinggi akan lebih merasakan 
ketenangan karena bisa berlapang dada atas semua konflik dengan individu lain (Bono, McCullough, \& Root, 2008).

Variabel yang kedua yaitu religiusitas. Pada variabel ini juga dibuat lima kategori yaitu agak rendah, rendah, sedang, agak tinggi dan tinggi. Pada kategori rendah terlihat skor total subjek yaitu dibawah 36,8 , subjek pada ketegori ini berjumlah $0(0 \%)$. Begitu juga dengan kelompok agak rendah yang memiliki nilai skor total diantara 36,8-51,4, kelompok ini juga tidak memiliki subjek (0\%). Kelompok sedang memiliki skor total subjek antara 51,4-80,6 yang dimana pada kelompok sedang terdapat 2 subjek $(1,3)$. Kelompok keempat dengan skor total subjek berkisar antara 80,6-95,2 memiliki jumlah subjek sebanyak 21 orang (14\%). Kemudian pada kelompok yang terakhir yaitu kategori tinggi dengan nilai skor total subjek diatas 95,2 memiliki subjek sebanyak 127 orang $(84,7 \%)$. Individu dengan tingkat religious tinggi akan memperlihatkan penerimaan secara positif terhadap berbagai peristiwa yang dialaminya dan patuh terhadap aturan-aturan yang dipercayainya, sedangkan individu dengan tingkat religious rendah akan merasakan bahwa dirinya adalah sebuah penentu atas hidup dan pengalamannya sendiri serta merasa tidak ada peraturan yang harus dipatuhinya (Ninin, 2019) .

\subsection{Analisis Pengaruh (Regression)}

Analisis Pengaruh atau analisis regression dalam penelitian ini menggunakan analisis regresi linear sederhana. Analisis ini dipergunakan guna untuk melihat pola variabel, interaksi antar variabel dan seberapa besar interaksi tersebut. selain itu, analisis ini juga digunakan untuk memprediksikan apakah variabel religiusitas dapat mempengaruhi variabel forgiveness. Pada penelitian ini analisis pengaruh dilihat melalui uji regresi linier sederhana. Adapun hasil uji regresi yang dapat dilihat pada tabel 5 .

Tabel 5. Uji Regresi

\begin{tabular}{cccc}
\hline Variabel & $R$ Square & Konstanta & Signifikansi \\
\hline Forgiveness & 0,326 & 0,198 & 0,000
\end{tabular}

Sumber: Hasil Penelitian (2020)

Hasil uji regresi pada variabel forgiveness dan variabel religiusitas mendapatkan hasil yaitu adanya pengaruh yang signifikan antara variabel forgiveness dengan variabel religiusitas. $\mathrm{Hal}$ ini dapat dilihat pada nilai signifikansi $0,000<0,05$. Nilai $R$ square menunjukan angka 0,326 , ini artinya variabel religiusitas mempengaruhi variabel forgiveness sebanyak $32,6 \%$ sedangkan sisahnya dipengaruhi oleh variabel lain. Kemudian setiap kenaikan satu tingkat nilai religiusitas akan menaikan nilai forgiveness sebanyak $19,8 \%$. Hal ini dapat dilihat pada nilai konstanta yang sebesar 0,198 . Hal ini sejalan dengan penelitian sebelumnya yang menyebutkan bahwa salah satu faktor yang mempengaruhi variabel forgiveness adalah religiusitas individu (Shabrina, Hasnawati, \& Fadhilah, 2008). Dalam penelitian yang dilakukan oleh Nuran (2011) juga ditemukan hasil yang serupa bahwa secara signifikansi, religiusitas dapat mempengaruhi forgiveness. 


\subsection{Analisis Uji Beda}

Analisis uji beda digunakan pada penelitian ini dengan tujuan untuk menganalisis lebih dalam lagi mengenai variabel forgiveness pada setiap kelompok subjek penelitian, apakah dalam masing-masing kelompok penelitian akan ditemukannya perbedaan atau tidak. Uji beda yang dilakukan pada penelitian ini, menggunakan analisis uji beda non-parametrik. Hal ini dikarenakan data variabel yang diteliti tidak terdistribusi secara normal (Santoso, 2010). Analisis uji beda pada kelompok jenis kelamin menggunakan uji beda mann whitney test, karena kelompok jenis kelamin hanya memiliki 2 kategori. Sedangkan untuk kelompok dengan 3 kategori, seperti kelompok kelas, menggunakan uji beda kruskall wallis test. Yang pertama akan dibahas dalam uji beda yaitu uji beda variablel forgiveness berdasarkan kelas.

Tabel 6. Uji Beda Forgiveness pada Kelompok Kelas

\begin{tabular}{ccccc}
\hline Kelompok & Kategori & Jumlah Subjek & Mean Rank & Signifikansi \\
\cline { 2 - 4 } Kelas & $\mathrm{X}$ & 22 & 67,00 & \\
\cline { 2 - 4 } & $\mathrm{XI}$ & 62 & 68,08 & 0,049 \\
& $\mathrm{XII}$ & 66 & 85,30 & \\
\hline
\end{tabular}

Sumber: Hasil Penelitian (2020)

Dilihat dari Tabel 6 diketahui kelas $\mathrm{X}$ berjumlah 22 orang, kelas XI berjumlah 62 orang dan kelas XII berjumlah 66 orang. Adapun nilai rata-rata pada tiap kelas (mean rank), kelas $X$ memiliki nilai rata-rata sebesar 67,00 , kelas XI memiliki nilai rata-rata sebesar 68,08 , dan kelas XII memiliki nilai rata-rata sebesar 85,30 . Jika dilihat dari nilai rata-rata, maka kelas XII memiliki tingkat forgiveness lebih tinggi dibandingkan kelas lainnya. Selanjutnya dapat dilihat juga nilai signifikansi yang ada sebesar 0,049 $<0,05$. Hasil ini menunjukan bahwa tingkat forgiveness individu memiliki perbedaan jika ditinjau dari tingkatan kelas. Semakin tinggi tingkatan kelas individu, maka semakin tinggi juga tingkat forgiveness. Kenaikan tingkatan kelas juga berhubungan dengan bertambahnya usia. Menurut pertambahan usia juga dapat meningkatkan perilaku forgiveness (Nashori, 2014). Kemudian dalam penelitian ini juga membahas uji beda forgiveness ditinjau dari kelompok jenis kelamin.

Tabel 7. Uji Beda Forgiveness pada Kelompok Jenis Kelamin

\begin{tabular}{ccccc}
\hline Kelompok & Kategori & Jumlah Subjek & Mean Rank & Signifikansi \\
\hline \multirow{2}{*}{ Jenis Kelamin } & Laki-Laki & 32 & 75,70 & \multirow{2}{*}{0,976} \\
\cline { 2 - 4 } & Perempuan & 118 & 75,44 & \\
\hline
\end{tabular}

Sumber: Hasil Penelitian (2020)

Tabel 7 memperlihatkan uji beda forgiveness pada kelompok jenis kelamin. Dalam tabel tersebut dapat dilihat jumlah subjek berjenis kelamin laki-laki sebanyak 32 orang dan subjek berjenis kelamin perempuan sebanyak 118 orang. Selanjutnya ditinjau dari kolom nilai rata-rata (mean rank), subjek laki-laki memiliki nilai rata-rata sebesar 75,70 dan pada subjek perempuan memiliki nilai rata-rata sebesar 75,44 . Walaupun nilai rata-rata (mean rank) menunjukan tingkat forgiveness laki-laki lebih tinggi daripada perempuan $(75,70>75,44)$, nilai rata-rata ini hanya memiliki perbedaan yang tipis sekali. Hasil ini sejalan dengan penelitian sebelumnya yang menyebutkan bahwa laki-laki memiliki kemauan yang lebih tinggi untuk memaafkan daripada 
perempuan (Utami, 2016). Hal ini dikarenakan laki-laki lebih suka berpikir tentang masa depan (masa yang akan datang), laki-laki juga lebih mudah menanam rasa percaya kepada individu lain. Sedangkan perempuan lebih cenderung sulit untuk memaafkan individu lain karena perempuan menggunakan perasaannya sebagai wadah untuk mengontrol dirinya (Wu, Sun, Miao, Yu, \& Wang, 2011). Kemudian, dilihat dari nilai signifikansi yang sebesar 0,976 $>0,05$, hal ini menunjukan bahwa tingkat forgiveness individu pada penelitian ini tidak memiliki perbedaan yang signifikan jika ditinjau dari kelompok jenis kelamin. Hasil ini memiliki hasil yang sama dengan penelitian sebelumnya, dimana ditemukan juga bahwa tidak ditemukan perbedaan yang signifikan perilaku forgiveness terhadap subjek penelitian laki-laki atau perempuan (Astuti, Kargenti, \& Marettih, 2018). Hasil yang sama juga ditemukan pada penelitian yang menyebutkan tidak adanya perbedaan perilaku forgiveness pada jenis kelamin laki-laki maupun perempuan (Toussaint \& Webb, 2005). Selain pada variabel forgiveness, uji beda juga dilakukan pada variabel religiusitas.

Tabel 8. Uji Beda Forgiveness pada Kelompok Kelas

\begin{tabular}{ccccc}
\hline Kelompok & Kategori & Jumlah Subjek & Mean Rank & Signifikansi \\
\cline { 2 - 4 } Kelas & $\mathrm{X}$ & 22 & 66,50 & \multirow{2}{*}{0,098} \\
& $\mathrm{XI}$ & 62 & 69,61 & \\
\cline { 2 - 4 } & $\mathrm{XII}$ & 66 & 84,03 \\
\hline
\end{tabular}

Sumber: Hasil Penelitian (2020)

Uji beda yang selanjutnya yaitu uji beda tingkat religiusitas ditinjau dari kelompok kelas. Dilihat dari tabel 7 , diketahui subjek dengan tingkat kelas $X$ sebanyak 22 subjek, tingkat $\mathrm{XI}$ sebanyak 62 subjek dan tingkat XII sebanyak 66 subjek. Nilai rata-rata (mean rank) pada kelompok kelas X sebesar 66,50, pada kelompok kelas XI sebesar 69,61 dan kemudian pada kelompok kelas XII sebesar 84,03. Dilhat dari nilai rata-rata tersebut, dapat diambil kesimpulan bahwa religiusitas individu akan semakin meningkat berbarengan dengan naiknya tingkatan kelas. Nilai signifikansi pada tabel 7 , menunjukan nilai sebesar $0,098>0,05$. Hal ini menunjukan bahwa religiusitas seseorang ditinjau dari kelompok kelas, tidak memiliki perbedaan yang signifikan. kenaikan tingkatan kelas menandakan usia yang juga ikut bertambah. Seperti yang dijelaskan oleh dalam penelitiannya, bahwa meningkatnya usia juga dapat meningkatkan religiusitas seseorang (Zakiyah \& Darodjat, 2020). Kemudian uji beda yang terakhir akan dilakukan pada variabel religiusitas berdasarkan jenis kelamin.

Tabel 8. Uji Beda Forgiveness pada Kelompok Jenis Kelamin

\begin{tabular}{ccccc}
\hline Kelompok & Kategori & Jumlah Subjek & Mean Rank & Signifikansi \\
\hline \multirow{2}{*}{ Jenis Kelamin } & Laki-Laki & 32 & 66,95 & \multirow{2}{*}{0,209} \\
\cline { 2 - 4 } & Perempuan & 118 & 77,82 & \\
\hline
\end{tabular}

Sumber: Hasil Penelitian (2020)

Dilihat dari tabel diatas, subjek dengan jenis kelamin laki-laki berjumlah sebanyak 32 subjek dan subjek dengan jenis kelamin perempuan berjumlah sebanyak 118 orang. Pada tabel 8 tersebut memperlihatkan laki-laki memiliki nilai rata-rata sebesar 66,95, sedangkan perempuan memiliki nilai rata-rata sebesar 77,82 . Hal ini menunjukan jika tingkat religiusitas 
perempuan lebih tinggi dibandingkan tingkat religiusitas laki-laki $(77,82>66,95)$. Pada kolom signifikansi memperlihatkan nilai signifikansi sebesar 0,209 $>0,05$. Hal ini menunjukan bahwa tingkatan religiusitas laki-laki dan perempuan tidak memiliki perbedaan yang signifikan. Hasil ini sejalan dengan penelitian sebelumnya yang juga menyebutkan bahwa perempuan lebih memiliki tingkat religious yang tinggi daripada laki-laki (Manning, 2010). Perempuan memiliki religious yang lebih tinggi karena perempuan lebih sering beribadah dan lebih meyakini agamanya sendiri, hal ini juga didorong dengan kewajiban perempuan saat menjadi ibu (Basri, 2015).

\section{Kesimpulan}

Penelitian ini berhasil mendapatkan beberapa fakta empirik. Penemuan pertama yaitu subjek penelitian rata-rata memiliki tingkat perilaku forgiveness agak tinggi dan tingkat religiusitas tinggi. Adapun hasil lainnya yaitu variabel religiusitas secara signifikan dapat mempengaruhi variabel forgiveness. Dengan ini dapat diketahui juga bahwa kedua variabel memiliki hubungan interaksi. Selain itu, melalui penelitian ini dapat diketahui juga bahwa variabel forgiveness tidak memiliki perbedaan yang signifikan bila ditinjau dari kelompok jenis kelamin. Sedangkan pada variabel forgiveness bila ditinjau dari kelompok tingkatan kelas memiliki perbedaan yang signifikan. Kemudian pada variabel religiusitas tidak ditemukan perbedaan yang signifikan pada kelompok jenis kelamin. Begitu juga dengan variabel religiusitas bila ditinjau dari kelompok tingkatan kelas, tidak ditemukan perbedaan yang signifikan. masukkan untuk penelitian kedepannya yaitu dapat untuk menganalisis variabel forgiveness pada subjek dengan rentan usia dewasa. Hal ini diperlukan untuk melihat proses perkembangan forgiveness dari segi usia.

\section{Daftar Pustaka}

Acharya, A. S., Prakash, A., Saxena, P., \& Nigam, A. (2013). Sampling: why and how of it? Indian Journal of Medical Specialities, 4(2), 3-7. https://doi.org/10.7713/ijms.2013.0032

Alentina, C. (2016). Memaafkan (Forgiveness) Dalam Konflik Hubungan Persahabatan. Jurnal IImiah Psikologi Gunadarma, 9(2), 100491. https://doi.org/10.35760/psi

Amrila, T. K., \& Widodo, P. B. (2015). Religiusitas Dan Pemaafan Dalam Konflik Organisasi Pada Aktivis Islam Di Kampus Universitas Diponegoro. Empati, 4(4), 287-292.

Astuti, W., Kargenti, A., \& Marettih, E. (2018). Apakah Pemaafan Berkorelasi dengan Psychological Well-Being pada Remaja yang Tinggal di Panti Asuhan? Jurnal IImu Perilaku, 2(1), 41-53.

Aviyah, E., \& Farid, M. (2014). Religiusitas, Kontrol Diri, dan Kenakalan Remaja. Persona Jurnal Psikologi Indonesia, 3(2), 126-129.

Azwar, S. (2017). Penyusunan Skala Psikologi. Yogyakarta: Pustaka Pelajar.

Basri, Y. M. (2015). Pengaruh Gender Religiusitas dan Sikap Love of Money Pada Persepsi Etika Penggelapan Pajak Mahasiswa Akuntansi. Jurnal Ilmiah Akuntansi Dan Bisnis, 
10(1), 45-54.

Bono, G., McCullough, M. E., \& Root, L. M. (2008). Forgiveness, feeling connected to others, and well-being: Two longitudinal studies. Personality and Social Psychology Bulletin, 34(2), 182-195. https://doi.org/10.1177/0146167207310025

Colegrove, V. M., Havighurst, S. S., Kehoe, C. E., \& Jacobsen, S. L. (2018). Pilot randomized controlled trial of Tuning Relationships with Music: Intervention for parents with a trauma history and their adolescent. Child Abuse and Neglect, 79(February), 259-268. https://doi.org/10.1016/j.chiabu.2018.02.017

Fox, A., \& Thomas, T. (2008). Impact of religious affiliation and religiosity on forgiveness. Australian Psychological Society, 43(September), 175-185. https://doi.org/10.1080/00050060701687710

Goss, S. M. (2002). Interpersonal forgiveness in elementary school- aged children.

Hutahaean, E. S. H., Corsini, A., Nugraha, W., Perdini, T. A., Bastoro, R., \& Marbun, R. (2020). Analysis of Parenting, Self-Control, and Personality Morality as Factors of Juvenile Delinquency in the City of Bekasi. Jurnal Psikologi, 16(1), 11-23. Retrieved from lipi.go.id Jaya, Maryana Kuswandi, D., \& Mulyadi, E. S. (2012). Pengaruh Kecerdasan Emosional Terhadap Kinerja Karyawan Pada Kantor Kementrian Agama Kabupaten Karawang. Manajemen, 10(1), 1038-1046.

Junaedi, A. (2019). Penanaman Nilai-Nilai Pendidikan Agama Islam Sejak Dini Bagi Pembentukan Karakter Siswa di RA Al-Falah Desa Pegagan Kidul Kecamatan Kapetakan Kabupaten Cirebon. Oasis: Jurnal IImiah Kajian Islam, 3(2), 101-119.

Karsidi, R. (2000). Pengembangan Instrumen Dalam Penelitian Sosial.

Khasan, M. (2017). Perspektif Islam Dan Psikologi Tentang Pemaafan. At-Taqaddum, 9(1), 69. https://doi.org/10.21580/at.v9i1.1788

Lin, W. N., Enright, R., \& Klatt, J. (2011). Forgiveness as character education for children and adolescents. Journal of Moral Education, 40(2), 237-253. https://doi.org/10.1080/03057240.2011.568106

Manik, R. (2017). Teknik Cognitive Restructuring untuk Meningkatkan Kecerdasan Emosi dan Forgiveness. Jurnal JUMPA, V(2), 67-78.

Manning, L. K. (2010). Gender and Religious Differences Associated with Volunteering in Later Life. Journal of Women \& Aging, 125-135. https://doi.org/10.1080/08952841003719224

McCullough, M. E., Rachal, K. C., \& Worthington, E. L. (1997). Interpersonal Forgiving in Close Relationships. Journal of Personality and Social Psychology, 73(2), 321-336. https://doi.org/10.1037/0022-3514.73.2.321

Mustika, F., \& Sahudra, T. M. (2018). Peranan Lingkungan Sosial terhadap Pembentukan Karakter Peduli Lingkungan Mahasiswa Pendidikan Geografi di Universitas Samudra Langsa. Jupiis: Jurnal Pendidikan IImu-IImu Sosial, 10(2), 235. https://doi.org/10.24114/jupiis.v10i2.11291

Nashori, F. (2014). Psikologi Pemaafan. Yogyakarta: Safiria Insania Press. 
Ninin, R. H. (2019). Diri Religius: Suatu Perspektif Psikologi Terhadap Kepribadian Akhlaqul Karimah. Psikis: Jurnal Psikologi Islami, 5(1), 1-12. https://doi.org/10.19109/psikis.v5i1.2041

Nuran. (2011). Faktor-Faktor Psikologis Yang Mempengaruhi Forgiveness Pada Istri Korban Kekerasan Dalam Rumah Tangga (Kdrt). Universitas Islam Negeri Syarif Hidayatullah Jakarta.

Nur Utami, A. C., \& Raharjo, S. T. (2019). Pola Asuh Orang Tua Dan Kenakalan Remaja. Focus : Jurnal Pekerjaan Sosial, 2(1), 150. https://doi.org/10.24198/focus.v2i1.23131

Nuwairah, N. (2015). Peran Keluarga dan Organisasi Remaja Masjid Dalam Dakwah Terhadap Remaja. Al-Hiwar, 3(6), 1-12.

Periantalo. (2016). Penelitian Kuantitatif Untuk Psikologi. Yogyakarta: Pustaka Pelajar.

Priyatno, D. (2012). Belajar Cepat Olah Data Statistik dengan SPSS (Ridwan, Ed.). Yogyakarta: CV Andi.

Rizqina, A. L., \& Suratman, B. (2020). Peran Pendidik Dalam Menanamkan Nilai Agama dan Moral Anak Usia Dini. Jurnal Kependidikan, 14(1), 18-29.

Ru, S., Diponegoro, A. M., Cahyo, H., \& Kistoro, A. (2020). Religiosity, Forgiveness, and Subjective Well-Being Among Adolescents in Religiosity, Forgiveness, and Subjective Well-Being Among Adolescents in Yogyakarta. (August).

Santoso, S. (2010). Statistik Non Parametrik (Konsep dan Aplikasi Dengan SPSS). Jakarta: PT Elex Media Komputindo.

Santrock, J. W. (2012). Life-Span Development (Perkembangan Masa Hidup) (13th ed.). Jakarta: Erlangga.

Shabrina, E., Hasnawati, \& Fadhilah. (2008). Gambaran perilaku pemaafan dalam konflik persahabatan. Jurnal Psikologi Islam. Retrieved from https://ejournal.uinib.ac.id/jurnal/index.php/alqalb/index

Simorangkir, S. L. B. L. (2019). Empati dan Religiositas Sebagai Prediktor terhadap Pemaafan pada Mahasiswa Sekolah Tinggi Teologi Salatiga. KHARISMATA: Jurnal Teologi Pantekosta, 2(1), 57-73. https://doi.org/10.47167/kharis.v2i1.25

Sugiyono. (2014). Metode Peneltian Kuantitatif Kualitatif dan $R \& D$. Bandung: Alfabeta.

Tisatin, N. N. (2019). Konflik Batin Seyla dalam Novel Lafaz Cinta Karya Sinta Yudisia Kajian Psikologi Sastra:Sigmund Freud.

Toussaint, L., \& Webb, J. R. (2005). Gender Defferences in the relationship Between Empathy and Forgiveness. 145(6), 1-12.

Utami, D. A. (2016). Kepercayaan Interpersonal Dengan Pemaafan Dalam Hubungan Persahabatan. Jurnal Ilmiah Psikologi Terapan, 3(1), 54-70. https://doi.org/10.22219/JIPT.V3I1.2126

Wade, N. G., \& Worthington, E. L. (2003). Overcoming Interpersonal Offense: Is Forgiveness the Only Way to Deal With Unforgiveness?

Wellek, R., \& Werren, A. (2014). Teori Kesusastraan. Jakarta: Gramedia. 
Widhiarso, W. (2012). Tanya Jawab tentang Uji Normalitas. 1-5.

Worthington, E. L. (2005). Handbook of Forgiveness. In Handbook of Forgiveness. https://doi.org/10.4324/9780203955673-38

Wu, J., Sun, S., Miao, T., Yu, L., \& Wang, F. (2011). Higher Ruminative Tendency of Anger in Trust-Forgiveness Young Adults. International Conference on Social Science and Humanity, 5, 511-515.

Zakiyah, \& Darodjat. (2020). Efektivitas Pembinaan Religiusitas Lansia Terhadap Perilaku Keagamaan (Studi Pada Lansia Aisyiyah Daerah Banyumas). 21(1), 69-80. 